\title{
Syn- and post-orogenic exhumation of metamorphic rocks in North
} \section{Aegean}

\author{
R. Lacassin ${ }^{1}$, N. Arnaud ${ }^{2}$, P. H. Leloup ${ }^{3}$, R. Armijo ${ }^{1}$, and B. Meyer ${ }^{4}$ \\ ${ }^{1}$ Institut de Physique du Globe de Paris, UMR7174 CNRS, Paris, France \\ ${ }^{2}$ Lab. Dynamique de la Lithosphère, UMR 5573 CNRS, USTL, Montpellier, France \\ ${ }^{3}$ Lab. Sciences de la Terre, UMR5570 CNRS, UCB Lyon, France \\ ${ }^{4}$ Lab. Tectonique, UMR7072 CNRS, Univ. P. et M. Curie, Paris, France
}

Received: 22 December 2006 - Published in eEarth Discuss.: 18 January 2007

Revised: 10 July 2007 - Accepted: 31 October 2007 - Published: 29 November 2007

\begin{abstract}
The Olympos-Ossa-Pelion (OOP) ranges, in NW Aegean, encompass Greece highest summit and are located near the extremity of the North Anatolian Fault (NAF). Structural and thermochronological data gathered in the OOP ranges show that the main exhumation of metamorphic nappes occurred in the Eocene, at ca. 43-39 Ma. This early exhumation, associated with ductile, then brittle-ductile normal faulting with northeastward transport, is coeval with orogenic shortening in the close area. Cooling rates, and likely exhumation, have been low between $\sim 40 \mathrm{Ma}$ and $\sim 20 \mathrm{Ma}$. ${ }^{40} \mathrm{Ar} /{ }^{39} \mathrm{Ar}$ crystallization ages (between 20 and $15 \mathrm{Ma}$ ) appears related to brittle-ductile normal faulting and likely associated with Neogene Aegean back-arc extension. The dating of a diabase dyke, and the geometry of associated brittle jointing, of onshore and offshore active normal faults suggest a shift in extension direction after $4 \mathrm{Ma}$, possibly in relation with the propagation of the NAF in northern Aegean.
\end{abstract}

\section{Introduction}

There is some consensus on the view that Aegean continental extension (Fig. 1) can be explained by some combination of gravitational forces in a thickened crust with pull forces associated with the retreat of the Hellenic Arc (e.g. McKenzie, 1978; Le Pichon and Angelier, 1981; Jolivet et al., 2003). It is also agreed that it postdates the compressional stacking of the Hellenic thrust-nappes, which is of upper Mesozoic to Lower-Cenozoic age in the internal part of the belt (e.g., Mercier et al., 1989; Schermer et al., 1990; Lips et al., 1998, 1999). However, the timing of inception of continental stretching, which is critical for constraining mechanical evo- lution models of the Aegean lithosphere, remains poorly constrained. Estimates range from 5 Ma (e.g. McKenzie, 1978) to more than $24 \mathrm{Ma}$ (e.g., Gautier and Brun, 1994; Gautier et al., 1999).

Evidence for extension in the Aegean comes from separate sets of observations. One set derives from seismology and earthquake geology. It focuses on the brittle, steeplydipping normal faults that account for the present-day deformation of the upper crust. A second set, derives from observations of older (Tertiary) ductile structures. It has been inferred from the latter that large amounts of extension of the lithosphere, associated with significant amounts of shear on shallow-dipping detachments at mid-crustal levels, induced rapid exhumation of metamorphic core complexes (e.g. Lister et al., 1984; Buick, 1991; Brun et al., 1994; Jolivet et al., 1994; Gautier et al., 1999). Finally a distinctive feature of the Aegean extension derives from recent tectonic and geodetic (GPS) observations: the mechanical interaction between the Aegean extension and the North Anatolian Fault (NAF), which propagated westward and likely entered the Aegean at $5 \mathrm{Ma}$ according to Armijo et al. $(1996,1999)$. Right-lateral motion along the NAF induced transtension in northern Aegean (Mc Neil et al., 2004) and enhanced extension in the North Aegean trough, Evvia and Corinth rifts (e.g. Flerit et al., 2004). The relations between orogenic shortening, continental extension and NAF propagation, and their temporal evolution remain subject of debate. Is the exhumation of metamorphic cores mainly due to extensional collapse or is it coeval with the stacking of the thrust-nappe edifice? To what extent is the Aegean extension controlled by motion on the NAF (or vice-versa)?

Correspondence to: R. Lacassin

(lacassin@ipgp.jussieu.fr)

Published by Copernicus Publications on behalf of the European Geosciences Union. 


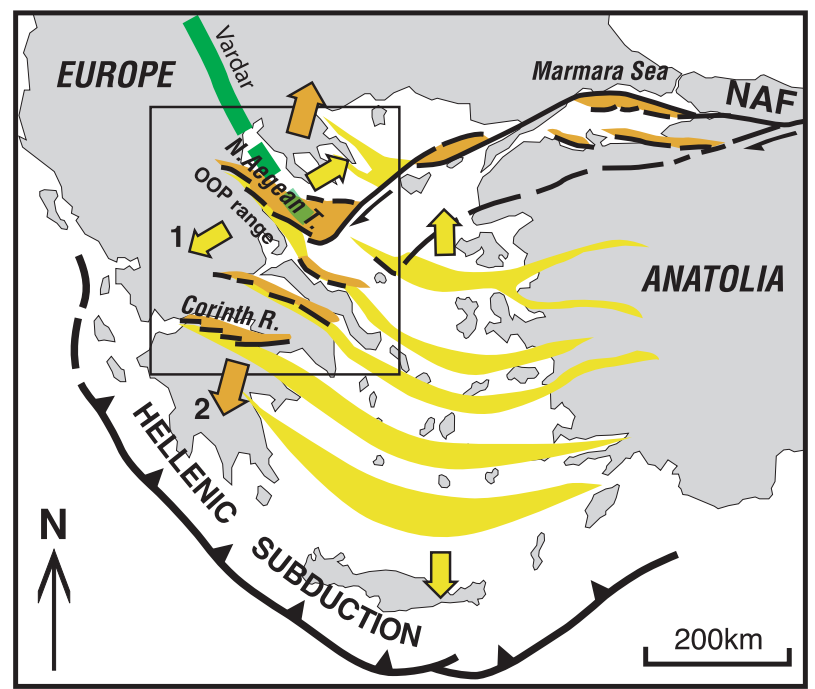

Fig. 1. Tectonic framework of Aegean extension (after Armijo et al., 1996). Active right-lateral motion occurs on two branches of North Anatolian Fault (NAF). Northern branch of NAF propagated west of Marmara Sea pull-apart basins around 5 Ma (Armijo et al, 1999). Late Cenozoic rifts (in orange) open to the SW of NAF extremity (North Aegean Trough, Corinth Rift) and reactivate, with some obliquity, Oligo-Pliocene extensional structures (in yellow). Orange and yellow arrows respectively indicate directions of presentday, and Oligo-Pliocene extension. OOP: Olympos, Ossa, Pelion. Green: approximate location of Vardar suture. Boxed area corresponds to Fig. 2.

The Olympos, Ossa and Pelion (OOP) ranges (Figs. 1, 2 and 3) are key to answer these questions because they are described as antiforms affecting thrust-nappes, are the footwall of active normal faults and show exposures of low-angle mylonites. They also encompass the highest summit of Greece and are located along the SW edge of the North Aegean trough at the extremity of the NAF. We report structural observations coupled with new ${ }^{40} \mathrm{Ar} /{ }^{39} \mathrm{Ar}$ dates in the time period covering the passage from compression to extension in the OOP ranges. Our structural observations and dates provide constraints both on the timing and on the mechanics of stretching in the Aegean.

\section{Exhumation of Olympos-Pelion nappe edifices}

\subsection{Overview of structure of Olympos-Ossa-Pelion ranges}

The OOP ranges constitute the uplifted and tilted footwall of NE-dipping normal faults (Figs. 3, 4). Offshore, in the W part of the North Aegean trough (Figs. 1, 2 and 3), $\mathrm{N} 90$ to $\mathrm{N} 120^{\circ} \mathrm{E}$ striking normal faults cut the top sedimentary layers and the seafloor topography (Laigle et al., 2000; Papanikolaou et al., 2002). These normal faults are connected to strike-slip fault segments splaying from the North-

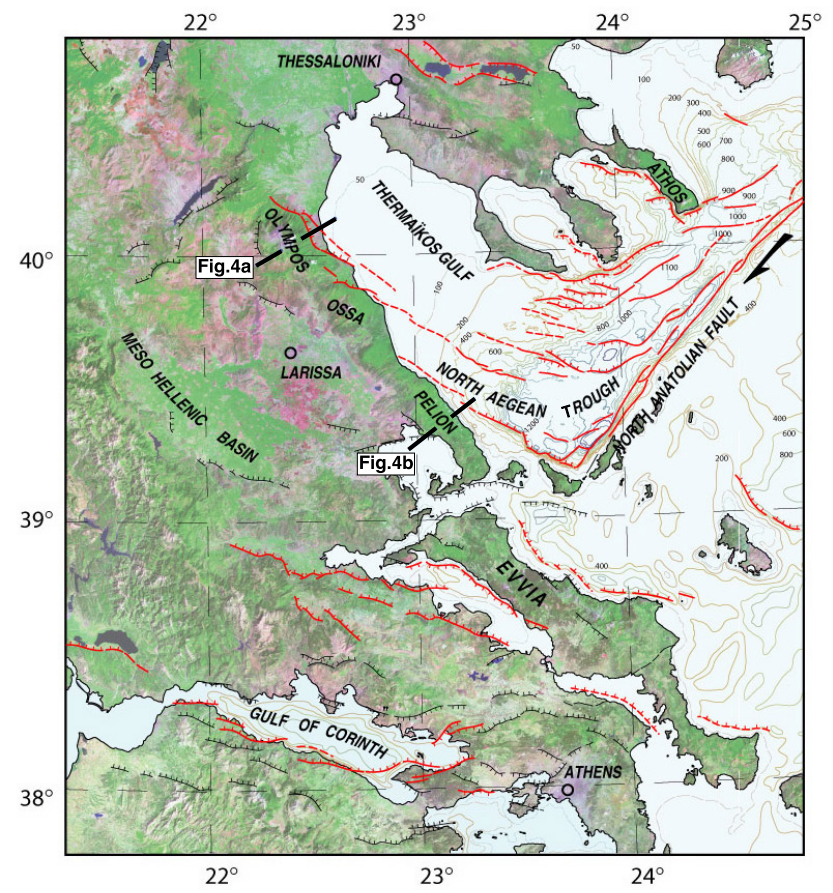

Fig. 2. Sketch map of recent faults in northern Aegean. Major active faults, in red, are NE-SW strike-slip segments belonging to the northern branch of the North Anatolian Fault (NAF), and NWSE to E-W normal faults; secondary faults are in black (onshore fault traces from Armijo et al., 1996, Goldworthy et al., 2002, and unpublished mapping by R. Armijo and B. Meyer; offshore faults in North Aegean trough and along NAF are from Papanikolaou et al., 2002, modified). Background image: NASA Landsat TM Mosaic (https://zulu.ssc.nasa.gov/mrsid/). Bathymetry from Mascle and Martin (1990) excepted in North Aegean Trough and along NAF (Papanikolaou et al., 2002).

ern branch of the NAF (Figs. 2, 3). They strike more easterly than the overall trend of the Pelion-Ossa coast and of the Thermaikos Gulf (Figs. 2, 3). In the prolongation of the offshore normal faults, the Mount Olympos piedmont is cut by several tens of meters high scarps (Figs. 3, 4). These scarps that correspond to recently formed normal faults, strike $\mathrm{N} 110$ to $\mathrm{N} 130^{\circ} \mathrm{E}$ oblique to the Olympos range-front fault, which strikes $\mathrm{N} 160^{\circ} \mathrm{E}$ on the average (Figs. 3, 4). More to the $\mathrm{S}$, near Volos, $\mathrm{W}$ of the Pelion, the young normal faults strike $\mathrm{N} 90$ to $\mathrm{N} 110^{\circ} \mathrm{E}$ and, together with earthquake fault-plane solutions (Hatzfeld et al., 1999; Goldsworthy et al., 2002; Mc Neil et al., 2004), indicate roughly N-S extension oblique to the trend of the Pelion range (Fig. 3).

The OOP ranges are antiforms, affecting the SW-verging thrust edifice of the Hellenic belt internal zones (e.g. Celet and Ferrière, 1978), and bounded to the NE by the Vardar suture, buried under the sediments of the Thermaikos Gulf and the North Aegean trough (Fig. 1).

The Olympos range (Fig. 4a), forms a window with para-autochthonous sediments in the core (Godfriaux, 1962) 
overlain by nappes of metamorphic rocks containing highpressure low-temperature (HP/LT) assemblages (Schermer, 1993). The core series (Mesozoic carbonate rocks) are topped by nummulite-bearing limestones of Paleocene to lower Ypresian age (Fleury and Godfriaux, 1974) conformably capped by undated detritic sediments (turbidites). Final emplacement of the metamorphic nappes onto these rocks thus occurred after the lower to middle Eocene $(\sim 50 \mathrm{Ma})$. The normal range-front-fault that bounds the eastern Olympos flank (Fig. 4a) displays triangular facets, suggesting steep normal faulting, more or less parallel to the foliation in units of marbles (Schermer, 1993; Jolivet and Patriat, 1999). Foliation dips 20 to $30^{\circ} \mathrm{E}$, with N $55^{\circ} \mathrm{E}-$ directed stretching lineations and down-to-the ENE ductile shear. This suggests that steep normal faulting has exhumed earlier ductile deformation that was occurring in a $\mathrm{N} 55^{\circ} \mathrm{E}$ direction, transverse to the strike of the range-front fault.

The thrust nappe edifice in the Ossa range, $\mathrm{S}$ of the Olympos, is less exhumed and dissected by erosion (Celet and Ferrière, 1978; Walcott, 1998). It shows a steep sea-facing range-front probably bounded to the NE by offshore active normal faults. Further S, the Pelion range (Figs. 3, 4b), made of gneisses and micaschists interlayered with marbles and locally serpentinite slices, is considered to be the equivalent of the Ossa-Olympos nappe-stack, with some mélange (Celet and Ferrière, 1978; Walcott, 1998). Metamorphism and deformation characters in the Pelion range are typical of relatively low P-T conditions (greenschist facies) although remnants of HP/LT assemblages are locally found (Walcott, 1998). The presence of raised fossil marine beaches along the eastern Pelion coast attests to recent uplift probably driven by offshore faults. E-dipping units, forming the E flank of the range (Fig. 4b), show greenschist facies foliation dipping 10 to $20^{\circ} \mathrm{NE}$ and $\sim \mathrm{N} 45^{\circ}$ E stretching lineations (Walcott, 1998) associated with dominantly northeastward shear (Figs. 5a, b). Macro- (Fig. 5b) and micro- (Figs. 5c, d) textures of mylonitic gneisses are typical of ductile deformation at medium temperature $>300^{\circ} \mathrm{C}$ (e.g. Passchier and Trouw, 1998). Lower grade, NE-dipping brittle-ductile shear-zones affect these units and mark often the contacts between them. At the outcrop-scale, the flat-lying foliation is overprinted by steeper brittle-ductile shears and by nearly vertical joints (Fig. 5e), implying an evolution under decreasing PT conditions down below those of the brittle-ductile transition $\left(\sim 300^{\circ} \mathrm{C}\right)$.

2.2 Geochronology, cooling history of the OOP ranges and evidence for Eocene exhumation

\subsubsection{Summary of previous geochronological studies}

Published results of ${ }^{40} \mathrm{Ar} /{ }^{39} \mathrm{Ar}$ dating on white micas (WM) and feldspars from the OOP ranges (Schermer et al., 1990; Lips et al., 1998, 1999) are summarized in Table 1.

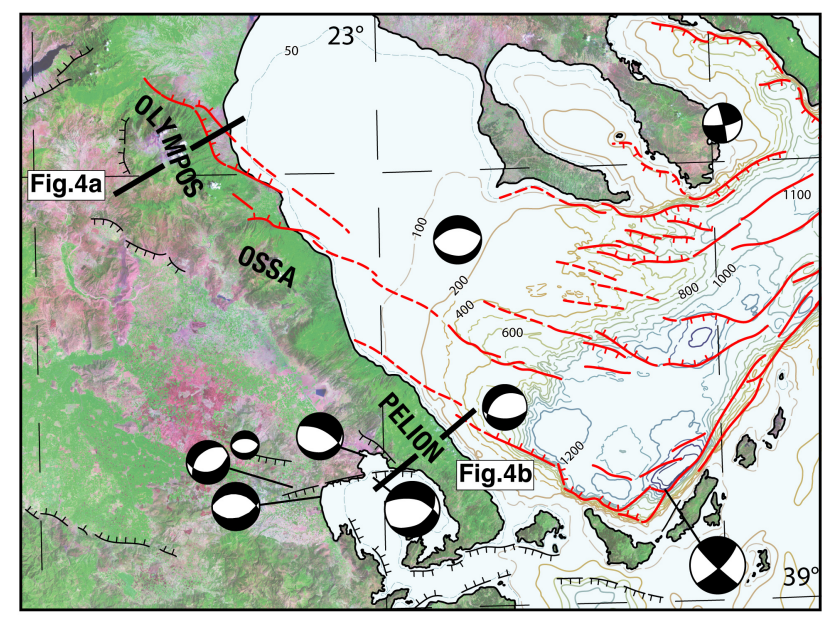

Fig. 3. Enlargement of map of Figure 2 showing Olympos-OssaPelion ranges, NAF southwestern tip and north Aegean trough. Around Pelion, fault plane solutions of normal faulting earthquakes (Hatzfeld et al., 1999; Goldworthy et al., 2002; Mc Neil et al., 2004), indicates $\sim$ N-S extension (see also Fig. 8 in Hatzfeld et al., 1999).

In the Olympos, most phengites and one microcline show age gradients in their spectra, with low temperature (LT) steps between $\sim 36$ and $42 \mathrm{Ma}$, and high temperature (HT) steps between 53 and $100 \mathrm{Ma}$ (Table 1). Other phengites yield plateau or isochron ages between $\sim 40$ and $60 \mathrm{Ma}$. This was interpreted as an evidence for several phases of nappe stacking and metamorphism starting at $\sim 100 \mathrm{Ma}$ and ending at $\sim 40 \mathrm{Ma}$ (Schermer et al., 1990). In such a context the LT steps are a product of cooling and successive reheating inducing argon loss, and cannot be simply used as cooling ages corresponding to a unique closure temperature. However it suggests that no significant reheating above phengite closure temperature $\left(\sim 350^{\circ} \mathrm{C}\right)$ has happened since that time. Microclines generally show diffusive gradients with younger LT steps between $\sim 17$ and $28 \mathrm{Ma}$ (Table 1), suggesting enhanced cooling at these ages (Schermer et al., 1990).

In the Ossa range, all but one (WM3) of Lips et al.'s (1998) recrystallized WM ages are older than $50 \mathrm{Ma}(\sim 55 \mathrm{Ma}$ in greenschist mylonites, 78-85 Ma in blueschist mylonites) while porphyroclasts give 293-102 Ma cooling ages (Table 1). Lips et al. (1998) infer the following history: cooling below WM closure temperature $\left(\sim 350^{\circ} \mathrm{C}\right)$ before $102 \mathrm{Ma}$, thrusting events at $78-85 \mathrm{Ma}$ during blueschist metamorphism, and at $54-55 \mathrm{Ma}$ during cooling below $300^{\circ} \mathrm{C}$. The last event could have lasted up to $45 \mathrm{Ma}$ (WM3 age), time since which the whole Ossa thrust-stack is at temperatures too low for ductile deformation.

As in the Ossa range, the ages of WM porphyroclasts from the Pelion are Paleozoic or lower Cretaceous (95 Ma) suggesting that Tertiary deformation occurred below $\sim 350^{\circ} \mathrm{C}$ (Lips et al., 1999). All but one (WM9 54 Ma) ages of 
Table 1. Summary of published Ar-Ar ages from the Olympos - Ossa - Pelion ranges.

\begin{tabular}{|c|c|c|c|}
\hline Unit & Mineral (sample $\mathrm{N}^{\circ}$ ) & Age & Remarks \\
\hline \multicolumn{4}{|c|}{ Mount Olympos - Schermer et al. (1990) } \\
\hline \multirow[t]{3}{*}{ Unit: Ambelakia } & Phengite (A1) & $39.6 \pm 0.9$ & Plateau age \\
\hline & Phengite (A2-3) & $37-100(\mathrm{~A} 2)$ & Gradient in age spectrum \\
\hline & & $32-69$ (A3) & \\
\hline \multirow[t]{15}{*}{ Unit: Pierien } & Phengite (P1) & $57 \pm 1.8(\mathrm{HT})$ & $\begin{array}{l}\text { HT plateau age, LT gradient down to } \\
45 \mathrm{Ma}\end{array}$ \\
\hline & Microcline (P1) & $28-49.6$ & Diffusive gradient - LT steps at $\sim 28 \mathrm{Ma}$ \\
\hline & Phengite (P2-3) & $40-56(\mathrm{P} 2)$ & Gradient in spectrum \\
\hline & & $36-55(\mathrm{P} 3)$ & \\
\hline & Phengite (P4) & $53.9 \pm 0.8$ (pla) & Plateau and isochron ages \\
\hline & & $53.1 \pm 0.7$ (iso) & \\
\hline & Phengite (P5) & $\begin{array}{l}61.7 \pm 0.8 \text { (pla) } \\
60.7 \pm 1.3 \text { (iso) }\end{array}$ & $\begin{array}{l}\text { HT plateau/isochrone age, LT gradient } \\
\text { down to } 41 \mathrm{Ma}\end{array}$ \\
\hline & Phengite (P6) & $\begin{array}{l}57-66 \text { (grad) } \\
60.3 \pm 1.4 \text { (iso) }\end{array}$ & Gradient spectrum - Isochrone age \\
\hline & Microcline (P7) [1] & $36-84$ & Diffusive gradient - LT steps at $\sim 36 \mathrm{Ma}$ \\
\hline & Microcline (P8) & $23-45.5$ & Diffusive gradient - LT steps at $\sim 24 \mathrm{Ma}$ \\
\hline & Phengite (P9-10-11) & $38-58(\mathrm{P} 9)$ & Gradient in spectrum \\
\hline & & $42-59(\mathrm{P} 10)$ & \\
\hline & & $40-72.6(\mathrm{P} 11)$ & \\
\hline & Microcline (P10-11) & $16.25-56(\mathrm{P} 10)$ & Diffusive gradient - LT steps $\sim 17(\mathrm{P} 10)$ \\
\hline & & $19.5-53.5(\mathrm{P} 11)$ & and $20(\mathrm{P} 11)$ \\
\hline \multirow[t]{2}{*}{ Unit: Infrapierien } & Phengite (IP1) & $56-98$ & $\begin{array}{l}\text { Gradient in spectrum }-98 \pm 2.3 \mathrm{Ma} \\
\text { isochron on HT steps }\end{array}$ \\
\hline & Phengite (IP3) & $51-65$ & $\begin{array}{l}\text { Gradient in spectrum }-63.3 \pm 1.7 \mathrm{Ma} \text { on } \\
\text { HT steps }\end{array}$ \\
\hline Notes & \multicolumn{3}{|c|}{$\begin{array}{l}\text { [1] Weakly deformed granodiorite with } \sim 295 \mathrm{Ma} \text { hornblende and biotite cooling } \\
\text { ages. }\end{array}$} \\
\hline \multicolumn{4}{|c|}{ Ossa - Lips et al. (1998) } \\
\hline \multirow{5}{*}{$\begin{array}{l}\text { Allochtoneous units } \\
\text { (W flank of Ossa) }\end{array}$} & WM 1 [2] & $54.2 \pm 2.8$ & Plateau age - age of mylonitic fabric \\
\hline & WM 3 & $45.5 \pm 1.4$ & id- \\
\hline & WM 138 & $53.7 \pm 3.6$ & id- \\
\hline & WM 146 & $55.4 \pm 1.7$ & id- \\
\hline & WM 149 & $55.8 \pm 4.0$ & id- \\
\hline Notes & \multicolumn{3}{|c|}{$\begin{array}{l}\text { [2] White micas (WM) often show two populations in each sample (porphyroclasts, } \\
\text { fine-grained micas in mylonitic foliation). WM Porphyroclasts gave cooling ages } \\
\text { between ca. } 293 \text { and } 102 \mathrm{Ma} \text {. We only report in this table the ages of WM in green- } \\
\text { schist mylonitic fabrics. WM from blueschist mylonites yielded ages between ca. } 78 \\
\text { and } 85 \mathrm{Ma} \text { (fabric age). One biotite gave a well defined plateau at } 80.9 \pm 2.2 \mathrm{Ma} \\
\text { (cooling age). }\end{array}$} \\
\hline \multicolumn{4}{|c|}{ Pelion - Lips et al. (1999) } \\
\hline \multirow[t]{10}{*}{ Pelion massif } & WM 5 [3] & $37.1 \pm 1.1$ & Plateau age - age of mylonitic fabric \\
\hline & WM 5 & $21.5 \pm 1.8$ & id- \\
\hline & WM 5 & $15.5 \pm 3.2$ & id- \\
\hline & WM6 & $34.9 \pm 2.6$ & id- \\
\hline & WM 6 & $15.5 \pm 2.0$ & id- \\
\hline & WM 7 & $26.8 \pm 4.1$ & id- \\
\hline & WM 9 & $53.9 \pm 5.9$ & id- \\
\hline & WM 9 & $39.1 \pm 1.6$ & id- \\
\hline & WM 9 & $39.4 \pm 1.5$ & id- \\
\hline & WM 10 & $32.3 \pm 1.25$ & id- \\
\hline Notes & \multicolumn{3}{|c|}{$\begin{array}{l}\text { [3] We report Lips et al's results on white micas (WM) in greenschist mylonitic } \\
\text { fabrics from the Pelion massif. WM porphyroclasts from Pelion samples gave Pa- } \\
\text { leozoic }(293,305 \mathrm{Ma} \text { ) or Cretacous ages ( } 95 \mathrm{Ma}) \text {. WM from Antihassia (SW of } \\
\text { Olympos) and Mavrovouni (between Pelio and Ossa) metamorphic massifs yielded } \\
\text { Mesozoic cooling ages ( } 89 \text { to } 150 \mathrm{Ma}) \text {. }\end{array}$} \\
\hline
\end{tabular}




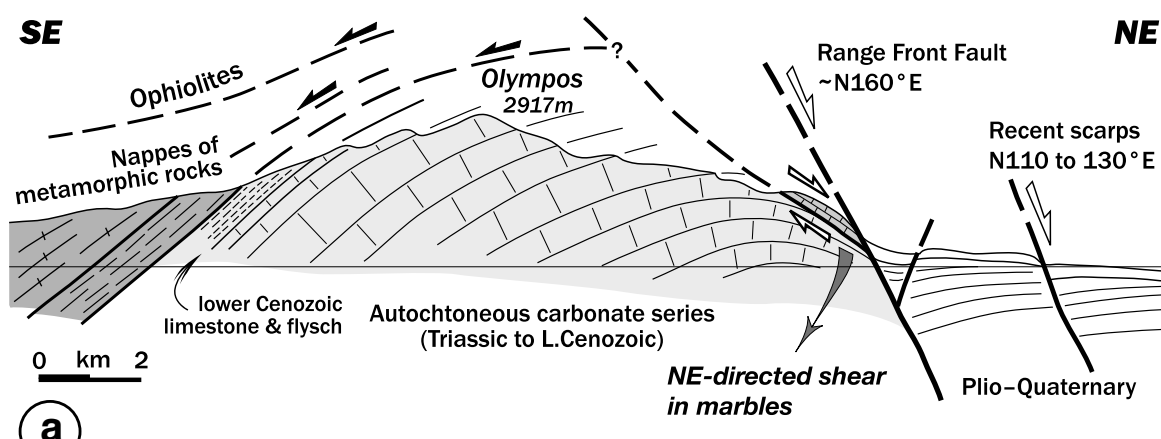

(a) in marbles

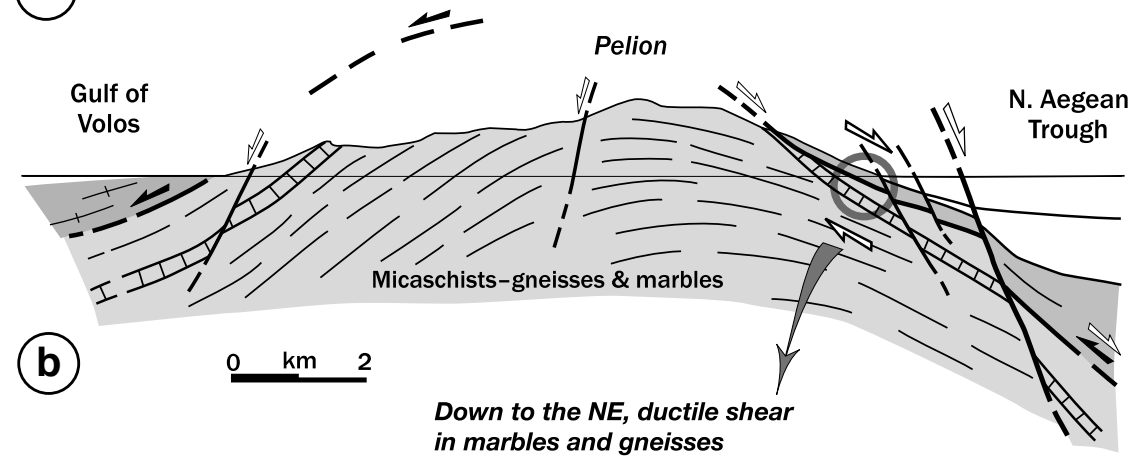

Fig. 4. Synthetic sections of Olympos (a) and Pelion (b) ranges, from geological maps and field observations (no vertical exageration). Olympos range displays nappes of metamorphic rocks (gneisses, schists, metasediments, ophiolites) overlying a core of Mesozoic to lower Tertiary sediments. It is cut by steep, NE-dipping recent normal faults (Schermer, 1993). Pelion range is made of metamorphic rocks equivalent to those of Olympos nappe stack. Its flank facing North Aegean trough shows E-dipping units with evidence of NE-ward ductile to brittle-ductile shear. Dated samples (Fig. 6, Table 2) come from these units. Black arrows: motion on thrust nappe contacts; open arrows: motion on normal faults.

fine-grained WM from mylonite fabrics are in the 40-15 Ma range (Table 1). Lips et al. (1999) relates these latter ages to crystallisation of WM below their closure temperature, during extensional foliation-parallel shear mostly towards the NE.

\subsubsection{Thermochronology of the Pelion metamorphic rocks}

New K-Feldspar ${ }^{40} \mathrm{Ar} /{ }^{39} \mathrm{Ar}$ thermochronology and mica dating from the eastern Pelion range provide further constrains on its cooling and exhumation history. In most cases pseudoplateaus were used to calculate the ages (see Appendix A). $\mathrm{K}$-feldspars are known to record cooling histories and especially rapid cooling events, which are theoretically marked by flat portions of the age spectra. These flat portions may be used to define pseudoplateaus or isochrons and to statistically calculate ages. Details on interpretation of feldspar age spectra are given in Appendix A together with analytical procedures. Appendix B lists analytical results, and Table 2 summarizes age results.

Two feldspars from mylonitic orthogneisses along a NESW section of the range (sample G5 from a quarry SE of Kalamaki at $350 \mathrm{~m}$ a.s.l.; $\mathrm{G} 7$ from the seashore $2 \mathrm{~km} \mathrm{NW}$ of the quarry) give a climbing age spectrum with a well-defined low temperature (LT) pseudo-plateau (5 to 35\% Argon re- lease) and a progressive increase towards older ages at high temperature steps (Fig. 6a and b). The first 5\% of each age spectrum is obscured by excess argon, correlated with strong chlorine content (see ${ }^{38} \mathrm{Ar} /{ }^{39} \mathrm{Ar}$ correlation) likely associated with fluid inclusions decrepitation at LT as is often the case in K-feldspars. Mean ages on the LT steps are confirmed by inverse isochron diagrams that include all young steps (thus more data than pseudo-plateaus) suggesting that excess argon can be corrected even in the first steps, and that pseudo-plateau ages are meaningful. Such pseudoplateaus followed by an age increase are sometimes interpreted as resulting from limited argon diffusion during rapid cooling events (Lovera et al., 1991), which would have occurred in the present case around $40 \mathrm{Ma}$. Note that G5 plateau is slightly older (42.0 $\pm 2.4 \mathrm{Ma})$ than that of G7 $(38.6 \pm 0.8 \mathrm{Ma})$. However, given that those feldspars are deformed and extracted from orthogneisses it is likely that simple diffusive laws from the K-feldspar lattice with permanent grain boundaries are violated. Rather, an alternative interpretation is that feldspar growth happened during nappe-stacking metamorphism around old feldspar cores. In this case pseudoplateaus correspond to closure to argon loss of those newly formed feldspar mantles after deformation. Given the fairly low argon retentivity in feldspars, this suggests that the dated 

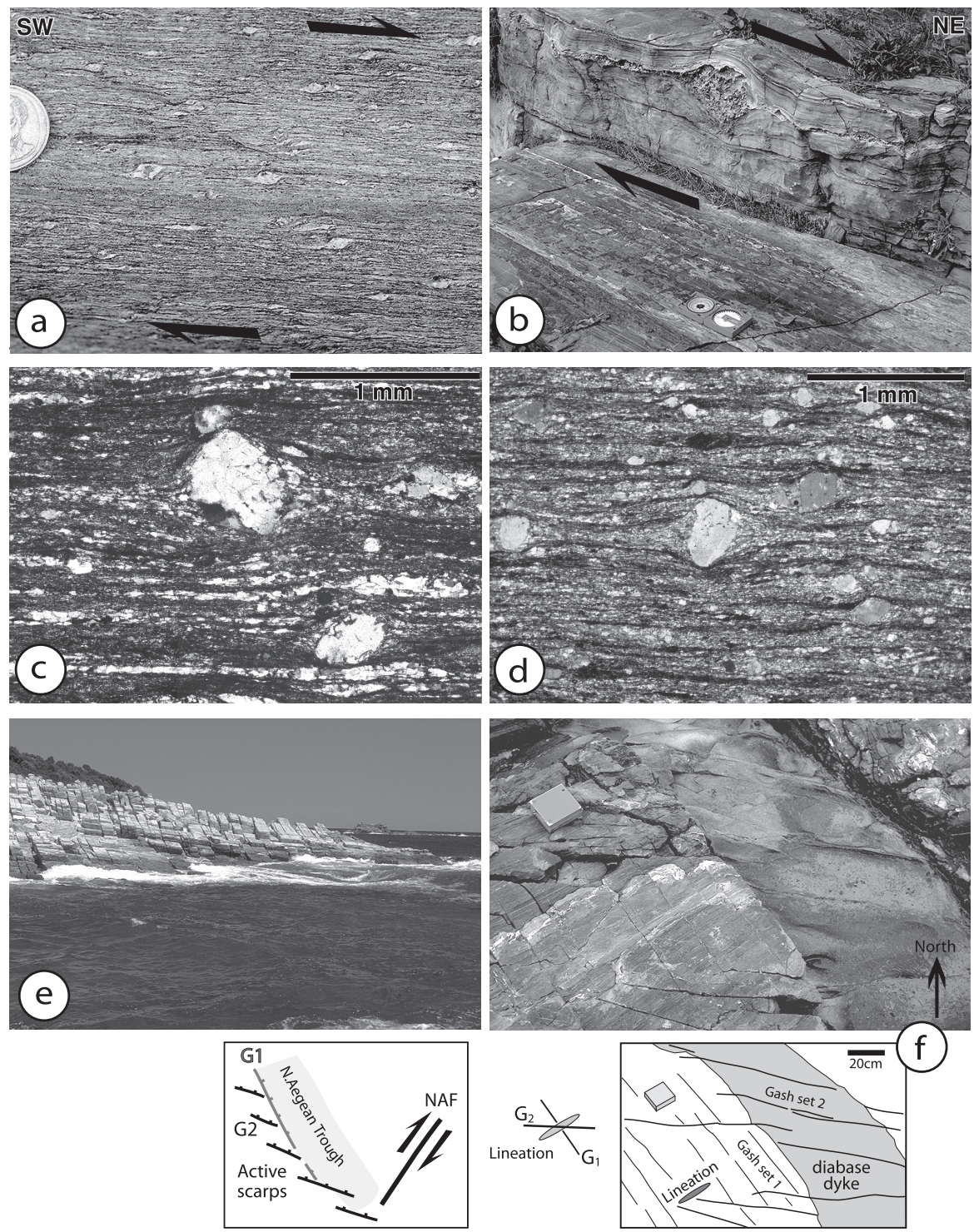

Fig. 5. Deformation characters along eastern Pelion coast with macroscopic evidence evidence of down to the NE (right) ductile shear in gneisses (a, equivalent to dated sample G7) and in marbles (b). Micro-textures of gneisses (c and d) show ribbons of recrystallized grains of quartz, recystallized mantles and elongated asymmetric tails around feldspar porphyroclasts, both typical of deformation at temperature $>300^{\circ} \mathrm{C}$. (e) along eastern Pelion flanck, pervasive joints and gashes, equivalent to G1 in (f), are parallel to trend of the coast. (f) a diabase dyke (samble G9611, 5.4 Ma, Fig. 6e), parallel to $\mathrm{N} 140^{\circ} \mathrm{E}$ gashes (Gash set 1, G1), intrudes earlier ductile fabric of marbles outlined by stretching lineations on foliation planes. It is cut obliquely by a second gash set (Gash set 2, G2) striking N $90^{\circ} \mathrm{E}$ on the average. Bottom -left inset shows analogy with regional-scale structures : G2 parallel to recent normal faults (Figs. 1, 2, 3); G1 parallel to older faults and to the overall trend of the Pelion coast.

samples were at temperatures below $200^{\circ} \mathrm{C}$ at $42-39 \mathrm{Ma}$, and that no later resetting is needed to explain the age spectrum. Such temperatures are too low for quartz plasticity and for only ductile deformation in gneissic rocks, implying that the ductile northeastward shear affecting the gneisses of the $\mathrm{E}$ Pelion flank have occurred before $\sim 40 \mathrm{Ma}$.

Mylonitic samples G9606 and G9607 (micaschists affected by northeastward shear) were sampled $2 \mathrm{~km} \mathrm{NW}$ of
Kalamaki quarry close to to a $\sim 10^{\circ} \mathrm{E}$ dipping brittle-ductile shear zone in units directly overlying the orthogneisses. Finegrained plagioclase (G9606) gives a fairly good plateau at $17.6 \pm 0.5 \mathrm{Ma}$ on two steps that correspond to more than 90\% of the gas release (Fig. 6d). Muscovite (G9607) shows a raising spectrum with a low temperature average age of $17.5 \pm 0.6 \mathrm{Ma}$ on the two first steps $(42 \%$ of gas release, Fig. 6c), prior to ages that rise up to $250 \mathrm{Ma}$. Such age 
Table 2. ${ }^{40} \mathrm{Ar} /{ }^{39} \mathrm{Ar}$ ages statistical analysis obtained on metamorphic minerals from the Pelion ranges. For each sample, the age spectra and inverse isochrons are analysed, with selected steps and resulting age, plus notes detailing the reasons for the choice of selected steps. Age spectra: the range of ages on the spectra is indicated, plus the calculated age on the selected steps below; inverse isochron: the calculated age is shown with selected steps below, the resulting ${ }^{40} \mathrm{Ar} /{ }^{36} \mathrm{Ar}$ intercept and the MSWD of the regression. Finally, when age spectra and inverse isochron analysis disagree on age results, a preferred age is proposed for the reason given in notes.

\begin{tabular}{|c|c|c|c|c|c|c|c|c|c|}
\hline Pelion - This work & Age spectra & & & Inverse isochron & & & & Preferred age & Note \\
\hline $\begin{array}{l}\text { Mineral/Sample } \\
\text { Lat Long coord. }\end{array}$ & $\begin{array}{l}\text { Range of age } \\
\text { in steps }\end{array}$ & $\begin{array}{l}\text { Plateau (P) or Pseudo- } \\
\text { plateau (PP) age (1) }\end{array}$ & Note (2) & Age (3) & ${ }^{40} \mathrm{Ar} /{ }^{36} \mathrm{Ar}$ & MSWD & Note & & \\
\hline $\begin{array}{l}\text { K-feldspar G5 } \\
\text { N } 39^{\circ} 19^{\prime} 50^{\prime \prime} \\
\text { E } 23^{\circ} 13^{\prime}\end{array}$ & 40 to 136 & $\begin{array}{l}42.0 \pm 2.4 \\
(\mathrm{PP} \text { on } 6-16,26 \%)\end{array}$ & LT steps & $\begin{array}{l}41.4 \pm 0.9 \\
(6-16)\end{array}$ & $290 \pm 15$ & 15,9 & & $42.0 \pm 2.4$ & $\begin{array}{l}\text { Age on LT steps, likely rep- } \\
\text { resent last cooling }\end{array}$ \\
\hline $\begin{array}{l}\text { K-feldspar G7 } \\
\text { N } 39^{\circ} 20^{\prime} 52^{\prime \prime} \\
\text { E } 23^{\circ} 13^{\prime} 38^{\prime \prime}\end{array}$ & 34 to 80 & $\begin{array}{l}38.6 \pm 0.8 \\
(\mathrm{PP} \text { on } 8-19,23.9 \%)\end{array}$ & LT steps & $\begin{array}{l}38.9 \pm 0.4 \\
(2,4,6,8-19)\end{array}$ & $288 \pm 21$ & 6,0 & $\begin{array}{l}\text { Isochron larger than plateau } \\
\text { on all LT points }\end{array}$ & $38.6 \pm 0.8$ & id- \\
\hline $\begin{array}{l}\text { Plagioclase G9606 } \\
\text { N } 39^{\circ} 21^{\prime} 18^{\prime \prime} \\
\text { E } 23^{\circ} 11^{\prime} 53^{\prime \prime}\end{array}$ & 16.8 to $>58$ & $\begin{array}{l}17.69 \pm 0.5 \\
\text { (PP on } 1-2,94 \%)\end{array}$ & $\begin{array}{l}\text { Used steps are the maxi- } \\
\text { mum of } \mathrm{K} / \mathrm{Ca} \text { on the spectra }\end{array}$ & - & - & - & & $17.6 \pm 0.5$ & \\
\hline $\begin{array}{l}\text { Muscovite G9607 } \\
\text { N } 39^{\circ} 21^{\prime} \\
\text { E } 23^{\circ} 21^{\prime}\end{array}$ & 18.5 to $>65$ & $\begin{array}{l}17.5 \pm 0.6 \\
(\mathrm{PP} \text { on } 1-2,42 \%)\end{array}$ & $\begin{array}{l}\text { Used steps are the maxi- } \\
\text { mum of } K / C a \text { on the spectra }\end{array}$ & $26.2 \pm 2.3(3-9)$ & $1322 \pm 55$ & 2,2 & $\begin{array}{l}\text { Isochron on HT points with } \\
\text { strong excess, probably un- } \\
\text { dercorrected and leading to } \\
\text { unrealistic age }\end{array}$ & $17.5 \pm 0.6$ & \\
\hline \multirow[t]{2}{*}{$\begin{array}{l}\text { Basalt G9611 } \\
\text { N } 39^{\circ} 22^{\prime} 40^{\prime \prime} \\
\text { E } 23^{\circ} 12^{\prime} 18^{\prime \prime}\end{array}$} & $\begin{array}{l}5.3 \text { to }>68 \\
\text { saddle shape }\end{array}$ & $\begin{array}{l}5.3 \pm 0.1 \\
(\mathrm{PP} \text { on } 3-4,47 \%)\end{array}$ & $\begin{array}{l}\text { Used steps are the maxi- } \\
\text { mum of } \mathrm{K} / \mathrm{Ca} \text { on the spectra }\end{array}$ & $5.2 \pm 0.7(1-4)$ & $312 \pm 17$ & 26,0 & $\begin{array}{l}\text { HT points with excess } \\
\text { rapidly increase MSWD }\end{array}$ & $3.9 \pm 0.2$ & $\begin{array}{l}\text { Saddle shape suggests ex- } \\
\text { cess revealed by isochron } \\
\text { with best MSWD. Age } \\
\text { probably close to real em- } \\
\text { placement age. }\end{array}$ \\
\hline & & & & $3.9 \pm 0.2(2-4)$ & $356 \pm 8$ & 0,6 & $\begin{array}{l}\text { Isochron restricted to first } 3 \\
\text { steps }\end{array}$ & & \\
\hline
\end{tabular}

(1) All ages are pseudpolateau ages (criteria are discussed in the text) given with numbers of steps used to calculate them and the amount of ${ }^{39}$ Ar realeased comprised in the "plateau".

(2) LT: low temperature, HT: high temperature

(3) Ages are given with numbers of steps used to calculate them.

spectra is interpreted as the result of mixing $\sim 18 \mathrm{Ma}$ muscovites with older metamorphic grains. Like those obtained by Lips et al. (1999) on fine-grained white-micas (40-15 Ma, Table 1 ), these $\sim 18 \mathrm{Ma}$ ages likely correspond to crystallization ages associated with continuing motion on foliation parallel shear zones. Altogether the data ages suggest that part of the penetrative northeastward shear occurred after the cooling event documented on K-feldspars, thus at relatively low temperature (less than $200^{\circ} \mathrm{C}$ ), probably by brittleductile shear localized in micaschists and marbles.

\section{Age constraints on brittle deformation along the edge of the Aegean through}

The ductile fabric associated with northeastward ductile shear along the E coast of Pelion is cut by numerous joints and tension gashes (Fig. 5e), which are generally filled with quartz and/or epidote-chlorite, or locally with diabase dykes (Fig. 5f). The joints are nearly vertical and strike $\mathrm{N} 140^{\circ} \mathrm{E}$ on the average. They are perpendicular to stretching lineations in the surrounding rocks and roughly parallel to the trend of the coast. An outcrop on the seashore near Milopotamos $(\sim 10 \mathrm{~km} \mathrm{~N}$ of section of Fig. $4 \mathrm{~b})$ displays a diabase dyke parallel to the $\mathrm{N} 140^{\circ} \mathrm{E}$ gash set (Fig. 5f). A younger set of vertical joints, striking $\mathrm{N} 80$ to $\mathrm{N} 100^{\circ} \mathrm{E}$, cuts obliquely the $\mathrm{N} 140^{\circ} \mathrm{E}$ gashes and the dyke, as well as the surrounding rock fabric (Fig. 5f). The sample G9611 taken from the diabase dyke has a saddle-shape age spectra characteristic of excess argon. The two steps with minimum age give $5.3 \pm 0.1 \mathrm{Ma}$ age while the inverse isochron age is $3.9 \pm 0.2 \mathrm{Ma}$ with a clear indication of excess argon (Fig. 6e). We interpret the isochron age as dating the emplacement of the dyke. The simplest interpretation of joint geometry and dyke age is that the $\mathrm{N} 140^{\circ} \mathrm{E}$ gashes formed at ca. $4 \mathrm{Ma}$ and that they were cut by the late, $\sim \mathrm{E}-\mathrm{W}$ joint set after $\sim 4 \mathrm{Ma}$.

\section{Timing of metamorphic rock exhumation and of North Anatolian fault propagation}

Our structural observation and ${ }^{40} \mathrm{Ar} /{ }^{39} \mathrm{Ar}$ data lead us to conclude that final exhumation of the OOP range resulted from three successive tectonic stages, all involving normal faulting (Fig. 7). Structural observations and cooling histories imply that in the Pelion range (Lips et al., 1999, this work), as well as in Ossa and Olympos (Schermer et al., 1990; Lips et al., 1998), the main exhumation of HP/LT metamorphic units occurred before or during the Eocene. In eastern Pelion, rapid cooling down to temperatures below $200^{\circ} \mathrm{C}$ occurred around $40 \mathrm{Ma}$. At that time, presently outcropping gneisses were brought to less than 10 to $5 \mathrm{~km}$ depth (for thermal gradients between 20 and $40^{\circ} / \mathrm{km}$ ), and the ductile, penetrative northeastward shear started to be more localized and brittle. The final stacking of thrust nappes occurred after the deposition of the post-Ypresian turbidites in the Olympos, thus after $\sim 50 \mathrm{Ma}$. Same age contraints on thrusting exist in Eubeoa, SE of Pelion (Dubois and Bignot, 1979). We thus infer that the main phase of exhumation, before and around $40 \mathrm{Ma}$, was coeval with the final stacking of thrust nappes, and older 

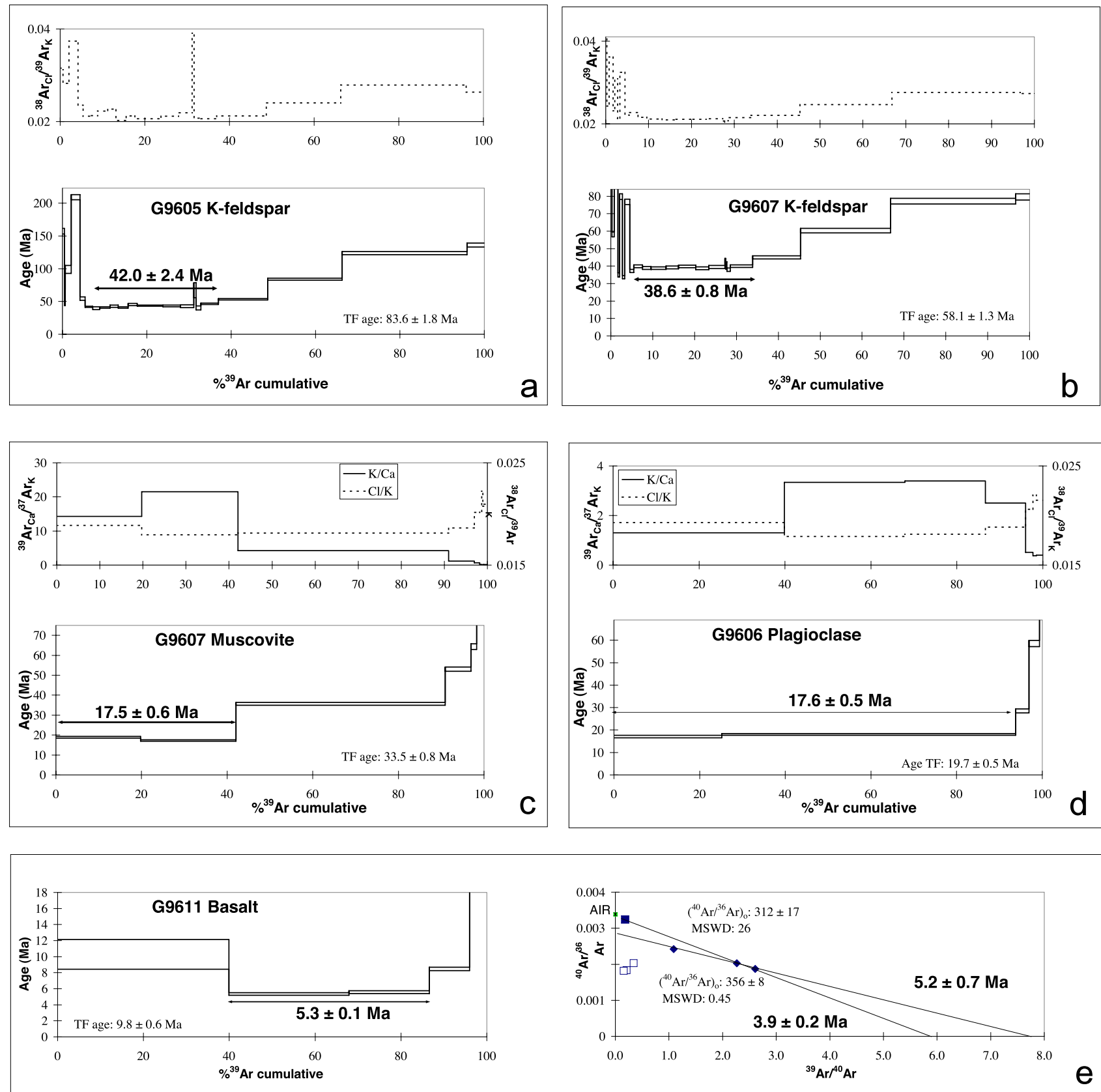

Fig. 6. ${ }^{40} \mathrm{Ar} /{ }^{39} \mathrm{Ar}$ dating of mylonites and schists. (a-b): K-feldspar ages spectra (samples G5 and G7). LT steps define pseudo-plateaus whose ages are interpreted as dating a ca.40Ma cooling event (see discussion in text). The steps of highest ages, obtained above start of melting of feldspar, were not included in the models, but probably underline the existence of a relict core of old age, similar to that in the muscovites (Lips et al., 1999). (c-d): age spectra of muscovite (G9607) and plagioclase (G9606), excess argon or inherited core for the muscovite is likely but not resolvable with the inverse isochrone approach. (e): basalt whole rock spectra and inverse isochron using the first four steps (with an age of ca. 5.2 Ma equal to the minimum age of the spectra) or the steps with lowest ages with an age $3.9 \mathrm{Ma}$ which is preferred, suggesting that the minimum of the saddle is a maximum age, as is usually the case when excess argon is present. Refer to Table 2 for precise Lat-Long location of samples.

than the onset of Aegean extension (Fig. 7). At this time, the northeastward foliation-parallel shear was probably related to normal ductile detachment at the top of a wedge extruding above a crustal thrust ramp (e.g., Jolivet et al., 2003; Ring et al., 2007). As some Pelion units remained at temperatures compatible with brittle-ductile shear and white-micas 


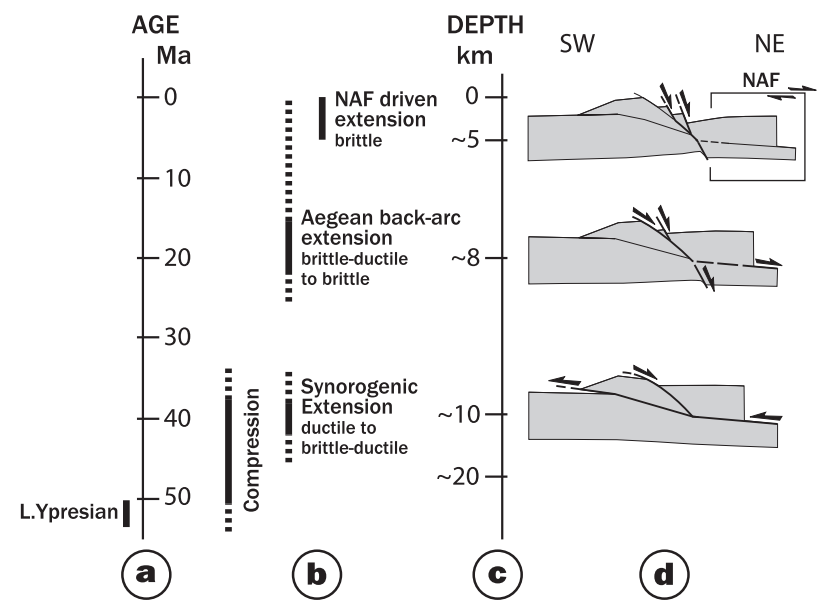

Fig. 7. Interpretative sketch showing evolution of deformation in the Olympos-Ossa-Pelion range. (a): linear time-scale. (b): main tectonic events. (c): qualitative estimate of depth of presently outcropping eastern Pelion rocks constrained by: 1 - cooling history of K-feldspars implying depth $<10 \mathrm{~km}$ after $\sim 40 \mathrm{Ma}, 2-$ low $\mathrm{T}^{\circ}$ crystallisation ages implying moderate exhumation between $\sim 40 \mathrm{Ma}$ and $\sim 20 \mathrm{Ma}, 3$ - existence of a large structural relief (several $\mathrm{km}$ ) due to recent motion on post $4 \mathrm{Ma}$ active faults. (d): crustal-scale sketches showing probable geometry of major faults.

crystallization until $\sim 18 \mathrm{Ma}$, we infer a modest amount of cooling (few tens of degrees) between $\sim 40 \mathrm{Ma}$ and $\sim 18 \mathrm{Ma}$ and thus a limited exhumation (Fig. 7). The low-temperature crystallization ages between 20 and $15 \mathrm{Ma}$ (Lips et al., 1999, this work), as well as the 17-28 Ma cooling event(s) in the Olympos range (Schermer et al., 1990), are ascribed to a second episode of extension nearly coaxial with the first one. The age of that event corresponds to the onset of Aegean back-arc extension (Fig. 7; Jolivet et al., 1994; Gautier and Brun, 1994).

The geometry and age of late brittle structures provide some hints on Pliocene-Quaternary kinematic evolution. The fact that the $\mathrm{N} 140^{\circ} \mathrm{E}$ gashes are perpendicular to the ductile stretching lineation could suggest that the extension direction was the same at $40 \mathrm{Ma}$ and $\sim 4 \mathrm{Ma}$. However, as the OOP range likely rotated 30 to 50 degrees clockwise since $15 \mathrm{Ma}$ (e.g., Van Hinsbergen et al., 2005), it appears that the $40 \mathrm{Ma}$ shear occurred in a more N-S direction than presently observed. During Aegean extension accompanying slab retreat, the ranges bounding extensional basins, such as the OOP range, rotated clockwize (e.g., Armijo et al., 1996; Van Hinsbergen et al., 2005) and, concurrently, the ongoing extension likely rotated to remain perpendicular to the ranges. Our data suggest a NE-SW extension direction at $4 \mathrm{Ma}$ along the Pelion coast. The latest $\sim \mathrm{E}-\mathrm{W}$ joints that cut the $4 \mathrm{Ma}$ dyke are parallel to newly formed onshore and offshore active normal faults and consistent with the moment tensor solutions of regional earthquakes (Fig. 3). This suggest a Pliocene-Quaternary shift towards a more N-S extension di- rection (e.g., Armijo et al., 1996; Goldworthy et al., 2002). We interpret this shift and the formation of these new faults as marking the onset of NAF-related deformation that would have occurred after $4 \mathrm{Ma}$ (Fig. 7) in line with the $\sim 5$ Ma propagation of NAF across the Dardanelles, $\mathrm{W}$ of the Marmara sea (Fig. 1), (Armijo et al., 1999).

Although our conclusions require more data (e.g. low $\mathrm{T}^{\circ}$ thermochronology) to be confirmed, we infer that multiphased exhumation histories, associated with changes in fault geometry and kinematics, like those we document in the OOP ranges, are probably common in the Aegean. In particular, a large part of the exhumation of metamorphic units may have been synorogenic, as suggested by Avigad and Garfunkel (1991) Jolivet and Patriat, (1999), Jolivet et al. (2003), and Ring et al. (2007) for instance. In addition, the inception of the most recent active fault system is not the straightforward continuation of the Aegean back-arc extension. Our age constrains, as well as the documented largescale changes in fault geometry and kinematics (e.g. Armijo et al., 1996; Flerit et al., 2004), suggest that it has been largely affected by the propagation of the NAF since $\sim 5 \mathrm{Ma}$.

\section{Appendix A}

\section{A1 ${ }^{40} \mathrm{Ar}^{39} \mathrm{Ar}$ techniques}

The minerals were separated using heavy liquids, a Frantz magnetic separator and finally by hand picking under a binocular microscope. The samples were irradiated at the Phoenix Memorial Laboratory reactor of the University of Michigan, in the L67 position for $20 \mathrm{~h}$ under a $10^{18}$ neutrons $\mathrm{cm}^{-2} \mathrm{~s}^{-1}$ flux. Irradiation interference on $\mathrm{K}, \mathrm{Ca}$ and $\mathrm{Cl}$ were corrected by irradiation of $\mathrm{KCl}$ and $\mathrm{CaF}_{2}$ pure salts. $J$ factors were estimated by the use of duplicates of the Fish Canyon sanidine standard with an age of $28.02 \mathrm{Ma}$ (Renne et al., 1998).

The samples were analyzed in Clermont-Ferrand. Samples were loaded in aluminum packets into a double vacuum Staudacher type furnace, which temperature is calibrated by means of a thermocouple, and step heated. The gas was purified by the means of cold traps with liquid air and $\mathrm{Al}-\mathrm{Zr}$ getters. Once cleaned, the gas was introduced into a VG3600 mass spectrometer, and 2 min were allowed for equilibration before analysis was done statically. Signals were measured by the mean of a Faraday cup with a resistor of $10^{11} \mathrm{ohm}$ for ${ }^{40} \mathrm{Ar}$ and ${ }^{39} \mathrm{Ar}$ while ${ }^{39} \mathrm{Ar},{ }^{38} \mathrm{Ar},{ }^{37} \mathrm{Ar}$ and ${ }^{36} \mathrm{Ar}$ were analyzed with a photomultiplier after interaction on a Daly plate. Gain between both collectors was estimated by duplicate analysis of ${ }^{39} \mathrm{Ar}$ on both during each analysis, and also by statistical analysis on a period of several years. This gain is in average of 95 and is know at better than $1.5 \%$. This error is included in the age calculation, along with analytical errors on each signal and errors on the blank values. Age plateau given are weighted mean plateaus which error takes the error on the $J$ factor into account. The isochron ages are obtained in an 
inverse isochron diagram of ${ }^{36} \mathrm{Ar} /{ }^{40} \mathrm{Ar}$ versus ${ }^{39} \mathrm{Ar} /{ }^{40} \mathrm{Ar}$ (Roddick, 1978; Roddick et al., 1980), which allows homogeneous excess components to be individualized in many occasions. Errors on age and intercept age include individual errors on each point and linear regression by York's method (1969). The goodness of it relative to individual errors is measured by Mean Square Weighted Deviation (MSWD).

For Micas, classical furnace step heating was conducted to extract age spectra and inverse isochrons. A more peculiar step heating schedule was conducted on K-feldspar in order to eventually retrieve diffusion characteristics (Harrison et al., 1991; Lovera et al., 1989, 1991). We also conducted duplicated isothermal step heating at low temperatures $\left(450-800^{\circ} \mathrm{C}\right)$, often yielding a sawtooth-shaped age spectrum where the second of the two stages is systematically younger and probably less affected by excess argon (e.g. Harrison et al., 1994).

\section{A2 Interpretation of age spectra, notably on K-felspars}

Compared to the definition corresponding to strict plateau criteria (Dalrymple and Lanphere, 1974; Berger and York,
1981) pseudoplateaus are sometimes used when a a significant amount of continuous steps overlap globally at $2 \sigma$, while contiguous steps do not, violating strict plateau criteria. This is especially true when minor diffusive loss or alteration is suggested. The use of pseudoplateaus or isochrons on series of steps on K-feldspars is justified by their peculiar composite structure allowing, in certain circumstances the extraction of cooling histories and especially rapid cooling events, which are theoretically marked by flat portions of the age spectra (Lovera et al., 1989, 1991).

\section{Appendix B}

\section{Table of analytical results}

Results ${ }^{40} \mathrm{Ar} /{ }^{39} \mathrm{Ar}$ dating by step heating analysis. For plagioclase, micas and basalt the table gives isotopic data errors and age, with the experimental ${ }^{39} \mathrm{Ar}$ moles released and cumulative $\%^{39} \mathrm{Ar}$. Ratios are corrected for blanks, analytical deviations and neutron interference reactions only. $J$ factor is given for each analysis.

\begin{tabular}{|c|c|c|c|c|c|c|c|c|c|c|}
\hline $\begin{array}{c}\text { Temp } \\
{ }^{\circ} \mathrm{C}\end{array}$ & ${ }^{40} \mathrm{Ar} /{ }^{39} \mathrm{Ar}$ & ${ }^{38} \mathrm{Ar} /{ }^{39} \mathrm{Ar}$ & ${ }^{37} \mathrm{Ar} /{ }^{39} \mathrm{Ar}$ & $\begin{array}{c}{ }^{36} \mathrm{Ar} /{ }^{39} \mathrm{Ar} \\
\left(10^{-3}\right)\end{array}$ & $\begin{array}{c}{ }^{39} \mathrm{Ar} \\
\left(10^{-14} \text { moles }\right)\end{array}$ & $\begin{array}{l}\mathrm{F}^{39} \mathrm{Ar} \\
\text { released }\end{array}$ & $\%^{40} \mathrm{Ar}^{*}$ & ${ }^{40} \mathrm{Ar} * / 39 \mathrm{Ar}$ & $\begin{array}{l}\text { Age } \\
\text { Ma }\end{array}$ & $\begin{array}{l} \pm 1 \mathrm{~s} \\
\mathrm{Ma}\end{array}$ \\
\hline G 96-6 & Plagioclase & $J=0.017154$ & & & & & & & & \\
\hline 700 & 8.188 & 0.025 & 0.024 & 26.340 & 7.68 & 25.15 & 6.66 & 0.55 & 16.79 & 0.56 \\
\hline 900 & 0.821 & 0.018 & 0.013 & 0.830 & 20.97 & 93.81 & 70.06 & 0.57 & 17.71 & 0.38 \\
\hline 1004 & 1.394 & 0.020 & 0.171 & 1.680 & 0.94 & 96.87 & 65.42 & 0.91 & 28.04 & 0.90 \\
\hline 1203 & 3.423 & 0.020 & 0.735 & 5.471 & 0.75 & 99.32 & 54.87 & 1.89 & 57.54 & 1.38 \\
\hline 1407 & 17.747 & 0.028 & 2.485 & 45.620 & 0.21 & 100.00 & 26.33 & 4.77 & 141.84 & 3.98 \\
\hline $\begin{array}{c}\text { Temp } \\
{ }^{\circ} \mathrm{C}\end{array}$ & ${ }^{40} \mathrm{Ar} /{ }^{39} \mathrm{Ar}$ & ${ }^{38} \mathrm{Ar} /{ }^{39} \mathrm{Ar}$ & ${ }^{37} \mathrm{Ar} /{ }^{39} \mathrm{Ar}$ & $\begin{array}{c}{ }^{36} \mathrm{Ar} /{ }^{39} \mathrm{Ar} \\
\left(10^{-3}\right)\end{array}$ & $\begin{array}{c}{ }^{39} \mathrm{Ar} \\
\left(10^{-14} \text { moles }\right)\end{array}$ & $\begin{array}{l}\mathrm{F}^{39} \mathrm{Ar} \\
\text { released }\end{array}$ & $\%{ }^{40} \mathrm{Ar}^{*}$ & ${ }^{40} \mathrm{Ar} * /{ }^{39} \mathrm{Ar}$ & $\begin{array}{l}\text { Age } \\
\text { Ma }\end{array}$ & $\begin{array}{l} \pm 1 \mathrm{~s} \\
\mathrm{Ma}\end{array}$ \\
\hline G 967 & Muscovite & $J=0.017146$ & & & & & & & & \\
\hline 700 & 5.402 & 0.022 & 0.135 & 16.561 & 16.56 & 19.75 & 11.14 & 0.60 & 18.54 & 0.45 \\
\hline 804 & 0.677 & 0.018 & 0.089 & 0.435 & 18.72 & 42.09 & 81.34 & 0.55 & 16.96 & 0.35 \\
\hline 914 & 1.236 & 0.018 & 0.452 & 0.410 & 41.09 & 90.96 & 92.27 & 1.14 & 35.05 & 0.71 \\
\hline 956 & 1.923 & 0.019 & 1.710 & 1.172 & 5.11 & 96.98 & 87.79 & 1.71 & 52.19 & 1.05 \\
\hline 1007 & 2.644 & 0.020 & 3.029 & 2.768 & 1.09 & 98.25 & 76.87 & 2.08 & 63.30 & 1.37 \\
\hline 1054 & 6.474 & 0.019 & 12.122 & 6.796 & 0.42 & 98.70 & 81.64 & 5.86 & 172.60 & 3.46 \\
\hline 1106 & 10.160 & 0.021 & 21.815 & 11.800 & 0.22 & 98.92 & 80.23 & 9.88 & 282.42 & 5.61 \\
\hline 1202 & 9.866 & 0.020 & 16.047 & 11.134 & 0.28 & 99.21 & 77.79 & 8.81 & 253.80 & 5.12 \\
\hline 1409 & 10.889 & 0.021 & 17.073 & 15.591 & 0.77 & 100.00 & 68.62 & 8.66 & 249.77 & 4.82 \\
\hline $\begin{array}{c}\text { Temp } \\
{ }^{\circ} \mathrm{C}\end{array}$ & ${ }^{40} \mathrm{Ar} /{ }^{39} \mathrm{Ar}$ & ${ }^{38} \mathrm{Ar} /{ }^{39} \mathrm{Ar}$ & ${ }^{37} \mathrm{Ar} /{ }^{39} \mathrm{Ar}$ & $\begin{array}{c}{ }^{36} \mathrm{Ar} /{ }^{39} \mathrm{Ar} \\
\left(10^{-3}\right)\end{array}$ & $\begin{array}{c}{ }^{39} \mathrm{Ar} \\
\left(10^{-14} \text { moles }\right)\end{array}$ & $\begin{array}{l}\mathrm{F}^{39} \mathrm{Ar} \\
\text { released }\end{array}$ & $\%^{40} \mathrm{Ar}^{*}$ & ${ }^{40} \mathrm{Ar} * / 39 \mathrm{Ar}$ & $\begin{array}{l}\text { Age } \\
\text { Ma }\end{array}$ & $\begin{array}{l} \pm 1 \mathrm{~s} \\
\mathrm{Ma}\end{array}$ \\
\hline G 9611 & Basalt & $J=0.017215$ & & & & & & & & \\
\hline 700 & 5.521 & 0.022 & 1.500 & 18.241 & 25.67 & 39.88 & 5.85 & 0.33 & 10.12 & 1.87 \\
\hline 800 & 0.382 & 0.018 & 0.580 & 0.843 & 17.89 & 67.89 & 44.24 & 0.17 & 5.26 & 0.14 \\
\hline 900 & 0.440 & 0.018 & 0.569 & 1.018 & 11.98 & 86.64 & 39.94 & 0.18 & 5.47 & 0.17 \\
\hline 1000 & 0.912 & 0.019 & 0.773 & 2.378 & 5.96 & 95.95 & 29.25 & 0.27 & 8.32 & 0.22 \\
\hline 1100 & 2.842 & 0.021 & 3.835 & 6.624 & 1.14 & 97.68 & 40.98 & 1.20 & 36.95 & 0.79 \\
\hline 1200 & 4.554 & 0.023 & 5.358 & 9.546 & 0.54 & 98.50 & 46.73 & 2.22 & 67.78 & 1.66 \\
\hline 1400 & 6.013 & 0.023 & 4.979 & 12.016 & 1.00 & 100.00 & 47.34 & 2.97 & 89.82 & 1.81 \\
\hline
\end{tabular}




\begin{tabular}{|c|c|c|c|c|c|c|c|c|c|c|}
\hline $\begin{array}{c}\text { Temp } \\
{ }^{\circ} \mathrm{C}\end{array}$ & ${ }^{40} \mathrm{Ar} /{ }^{39} \mathrm{Ar}$ & ${ }^{38} \mathrm{Ar} /{ }^{39} \mathrm{Ar}$ & ${ }^{37} \mathrm{Ar} /{ }^{39} \mathrm{Ar}$ & $\begin{array}{c}{ }^{36} \mathrm{Ar} /{ }^{39} \mathrm{Ar} \\
\left(10^{-3}\right)\end{array}$ & $\begin{array}{c}{ }^{39} \mathrm{Ar} \\
\left(10^{-14} \text { moles }\right)\end{array}$ & $\begin{array}{l}\mathrm{F}^{39} \mathrm{Ar} \\
\text { released }\end{array}$ & $\%^{40} \mathrm{Ar}^{*}$ & ${ }^{40} \mathrm{Ar} * / 39 \mathrm{Ar}$ & $\begin{array}{l}\text { Age } \\
\mathrm{Ma}\end{array}$ & $\begin{array}{c} \pm 1 \mathrm{~s} \\
\mathrm{Ma}\end{array}$ \\
\hline G 7 & K-feldspar & $J=0.007014$ & & $\mathrm{wt}=18.7 \mathrm{mg}$ & & & & & & \\
\hline 400 & 29.163 & 0.051 & 0.011 & 45.795 & 0.04 & 0.28 & 53.33 & 15.85 & 190.22 & 3.78 \\
\hline 400 & 7.836 & 0.025 & 0.004 & 11.070 & 0.07 & 0.79 & 55.37 & 4.60 & 57.24 & 1.40 \\
\hline 460 & 10.750 & 0.036 & 0.001 & 6.488 & 0.11 & 1.69 & 80.84 & 8.84 & 108.51 & 2.16 \\
\hline 460 & 4.810 & 0.023 & 0.003 & 7.027 & 0.05 & 2.12 & 50.86 & 2.74 & 34.38 & 1.25 \\
\hline 500 & 7.926 & 0.031 & 0.002 & 5.346 & 0.08 & 2.77 & 77.53 & 6.35 & 78.57 & 1.63 \\
\hline 500 & 4.468 & 0.021 & 0.002 & 6.192 & 0.07 & 3.29 & 55.16 & 2.64 & 33.13 & 0.88 \\
\hline 550 & 7.202 & 0.032 & 0.000 & 3.706 & 0.16 & 4.52 & 83.09 & 6.10 & 75.55 & 1.52 \\
\hline 550 & 3.594 & 0.022 & 0.000 & 2.194 & 0.12 & 5.48 & 75.96 & 2.93 & 36.66 & 0.88 \\
\hline 609 & 3.748 & 0.022 & 0.000 & 2.019 & 0.26 & 7.55 & 81.83 & 3.13 & 39.21 & 0.80 \\
\hline 655 & 3.442 & 0.021 & 0.000 & 1.208 & 0.26 & 9.59 & 86.90 & 3.06 & 38.33 & 0.79 \\
\hline 700 & 4.649 & 0.021 & 0.000 & 5.403 & 0.46 & 13.17 & 64.86 & 3.05 & 38.22 & 0.78 \\
\hline 750 & 3.359 & 0.020 & 0.000 & 0.845 & 0.38 & 16.13 & 90.32 & 3.08 & 38.60 & 0.78 \\
\hline 800 & 3.349 & 0.020 & 0.000 & 0.651 & 0.53 & 20.28 & 92.39 & 3.13 & 39.18 & 0.79 \\
\hline 800 & 3.198 & 0.020 & 0.000 & 0.416 & 0.39 & 23.37 & 92.27 & 3.05 & 38.15 & 0.80 \\
\hline 800 & 3.201 & 0.020 & 0.000 & 0.253 & 0.49 & 27.25 & 90.84 & 3.10 & 38.78 & 0.89 \\
\hline 700 & 3.397 & 0.020 & 0.000 & 0.000 & 0.03 & 27.47 & 59.18 & 3.37 & 42.11 & 1.66 \\
\hline 750 & 3.505 & 0.018 & 0.000 & 1.017 & 0.03 & 27.73 & 71.35 & 3.18 & 39.79 & 2.09 \\
\hline 800 & 3.260 & 0.020 & 0.001 & 0.874 & 0.11 & 28.56 & 83.81 & 2.98 & 37.28 & 0.97 \\
\hline 900 & 3.344 & 0.021 & 0.000 & 0.590 & 0.68 & 33.89 & 92.94 & 3.14 & 39.34 & 0.80 \\
\hline 1000 & 3.753 & 0.021 & 0.000 & 0.622 & 1.45 & 45.30 & 93.96 & 3.54 & 44.28 & 0.97 \\
\hline 1100 & 5.045 & 0.024 & 0.000 & 0.839 & 2.73 & 66.78 & 94.26 & 4.77 & 59.39 & 1.28 \\
\hline 1200 & 6.373 & 0.027 & 0.000 & 0.739 & 3.80 & 96.68 & 95.89 & 6.13 & 75.93 & 1.65 \\
\hline 1400 & 7.276 & 0.027 & 0.001 & 3.161 & 0.42 & 100.00 & 83.93 & 6.33 & 78.36 & 1.72 \\
\hline
\end{tabular}

\begin{tabular}{|c|c|c|c|c|c|c|c|c|c|c|}
\hline $\begin{array}{l}\text { Temp } \\
{ }^{\circ} \mathrm{C}\end{array}$ & ${ }^{40} \mathrm{Ar} /{ }^{39} \mathrm{Ar}$ & ${ }^{38} \mathrm{Ar} /{ }^{39} \mathrm{Ar}$ & ${ }^{37} \mathrm{Ar} /{ }^{39} \mathrm{Ar}$ & $\begin{array}{c}{ }^{36} \mathrm{Ar} /{ }^{39} \mathrm{Ar} \\
\left(10^{-3}\right)\end{array}$ & $\begin{array}{c}{ }^{39} \mathrm{Ar} \\
\left(10^{-14} \text { moles }\right)\end{array}$ & $\begin{array}{c}\mathrm{F}^{39} \mathrm{Ar} \\
\text { released }\end{array}$ & $\%^{40} \mathrm{Ar} *$ & ${ }^{40} \mathrm{Ar} *{ }^{39} \mathrm{Ar}$ & $\begin{array}{l}\text { Age } \\
\mathrm{Ma}\end{array}$ & $\begin{array}{c} \pm 1 \mathrm{~s} \\
\mathrm{Ma}\end{array}$ \\
\hline G5 & K-feldspar & $J=0.007019$ & & $\mathrm{wt}=7.1 \mathrm{mg}$ & & & & & & \\
\hline 394 & 23.068 & 0.038 & 0.002 & 35.499 & 0.02 & 0.49 & 0.51 & 12.77 & 154.91 & 4.16 \\
\hline 400 & 12.487 & 0.036 & 0.010 & 27.842 & 0.01 & 0.67 & 0.22 & 4.41 & 55.05 & 12.16 \\
\hline 452 & 11.028 & 0.030 & 0.000 & 10.788 & 0.06 & 2.06 & 0.53 & 7.90 & 97.35 & 6.22 \\
\hline 558 & 21.156 & 0.040 & 0.000 & 13.533 & 0.09 & 4.19 & 0.79 & 17.23 & 205.97 & 4.05 \\
\hline 558 & 5.624 & 0.024 & 0.001 & 4.556 & 0.05 & 5.39 & 0.60 & 4.30 & 53.68 & 2.67 \\
\hline 608 & 5.142 & 0.022 & 0.001 & 6.372 & 0.07 & 7.19 & 0.64 & 3.29 & 41.23 & 0.83 \\
\hline 608 & 3.935 & 0.022 & 0.000 & 2.798 & 0.07 & 8.86 & 0.62 & 3.12 & 39.13 & 1.98 \\
\hline 657 & 3.939 & 0.023 & 0.001 & 2.538 & 0.10 & 11.27 & 0.72 & 3.20 & 40.12 & 1.18 \\
\hline 657 & 3.719 & 0.023 & 0.001 & 1.194 & 0.08 & 13.20 & 0.72 & 3.37 & 42.21 & 1.82 \\
\hline 704 & 3.748 & 0.021 & 0.000 & 1.877 & 0.10 & 15.60 & 0.75 & 3.20 & 40.12 & 1.20 \\
\hline 704 & 3.789 & 0.021 & 0.000 & 0.783 & 0.08 & 17.69 & 0.75 & 3.56 & 44.56 & 1.77 \\
\hline 800 & 11.444 & 0.026 & 0.000 & 27.603 & 0.25 & 23.83 & 0.29 & 3.44 & 43.04 & 0.94 \\
\hline 785 & 3.886 & 0.021 & 0.001 & 1.675 & 0.17 & 27.98 & 0.73 & 3.40 & 42.55 & 1.48 \\
\hline 800 & 3.564 & 0.022 & 0.001 & 0.685 & 0.13 & 31.17 & 0.69 & 3.37 & 42.12 & 2.27 \\
\hline 700 & 5.329 & 0.039 & 0.010 & 0.000 & 0.02 & 31.67 & 0.22 & 5.33 & 66.26 & 11.43 \\
\hline 794 & 4.138 & 0.021 & 0.002 & 3.388 & 0.05 & 32.82 & 0.53 & 3.16 & 39.52 & 3.03 \\
\hline 896 & 3.928 & 0.021 & 0.000 & 0.895 & 0.17 & 36.98 & 0.86 & 3.67 & 45.86 & 1.08 \\
\hline 999 & 4.483 & 0.021 & 0.000 & 0.926 & 0.48 & 48.68 & 0.91 & 4.21 & 52.60 & 1.07 \\
\hline 1097 & 7.081 & 0.024 & 0.000 & 1.357 & 0.71 & 66.28 & 0.93 & 6.69 & 82.76 & 1.65 \\
\hline 1199 & 10.484 & 0.028 & 0.000 & 1.788 & 1.20 & 95.91 & 0.94 & 9.97 & 121.97 & 2.44 \\
\hline 1400 & 12.604 & 0.027 & 0.001 & 5.597 & 0.17 & 100.00 & 0.80 & 10.98 & 133.95 & 2.91 \\
\hline
\end{tabular}


Acknowledgements. This is IPGP contribution number 2308. We thank J. Wijsbrans, D. J. Van Hinsbergen and an anonymous reviewer for providing constructive in depth reviews. A. C. LaurentMorillon compiled and drew map of Figs. 2 and 3.

Edited by: J. Smit

\section{References}

Armijo, R., Meyer, B., King, G. C. P., Rigo, A., and Papanastassiou, D.: Quaternary evolution of the Corinth Rift and its implications for the late Cenozoic evolution of the Aegean, Geophys. J. I., 126, 11-53, 1996.

Armijo, R., Meyer, B., Hubert, A., and Barka, A.: Westward propagation of the North Anatolian Fault into the northern Aegean; timing and kinematics, Geology (Boulder), 27, 267-270, 1999.

Avigad, D. and Garfunkel, Z.: Uplift and exhumation of highpressure metamorphic terrains: the example of the cycladic blueschist belt (Aegean Sea), Tectonophysics, 188, 357-372, 1991.

Berger, G. W. and York, D.: Geothermometry from 40Ar/39Ar dating experiments, Geochemica Cosmochemica Acta, 45, 795$811,1981$.

Brun, J. P., Sokoutis, D., and Van den Driessche, J.: Analogue modeling of detachment fault systems and core complexes, Geology, 22, 319-322, 1994.

Buick, I. S.: The late alpine evolution of an extensional shear zone, Naxos, Greece, J. Geol. Soc. London, 148, 93-103, 1991.

Celet, P. and Ferrière, J. : Les Hellénides internes: le Pélagonien: Eclogae Geologicae Helveticae, 71, 467-495, 1978.

Dalrymple, G. B. and Lanphere, M. A.: 40Ar/ 39Ar age spectra of some undisturbed terrestrial samples, Geochimica et Cosmochimica Acta, 38, 715-738, 1974.

Dubois, R. and Bignot, G.: Présence d'un "hardground" nummulitique au sommet de la série crétacé d'Almyropotamos (Eubée méridionale, Grèce), C.R. Acad. Sc. Paris, 289, 993-995, 1979.

Flerit, F., Armijo, R., King, G., and Meyer B. : The mechanical interaction between the propagating North Anatolian Fault and the back-arc extension in the Aegean, Earth Planet. Sc. Lett., 224, 347-362, 2004

Fleury, J. J. and Godfriaux, I.: Arguments pour l'attribution de la série de la fenêtre de l'Olympe (Grèce) à la zone de Gavrovo Tripolitza: présence de fossiles du Maastrichtien et de l'Eocène inférieur (et moyen ?), Annales de la Société Géologique du Nord, 94, 149-156, 1974.

Godriaux, Y.: L'Olympe, une fenêtre tectonique dans les Hellénides internes, C.R. Acad. Sc. Paris, 255, 1761-1763, 1962.

Gautier, P. and Brun, J. P.: Ductile crust exhumation and extensional detachments in the central Aegean (Cyclades and Evvia Islands), Geodinamica Acta, 7, 57-85, 1994.

Gautier, P., Brun, J.-P., Moriceau, R., Sokoutis, D., Martinod, J., and Jolivet, L.: Timing, kinematics and cause of Aegean extension: a scenario based on a comparison with simple analogue experiments, Tectonophysics, 315, 31-72, 1999.

Goldsworthy, M., Jackson, J., and Haines, J.: The continuity of active fault systems in Greece, Geophys. J. Int., 148, 596-618, 2002

Harrison, T. M., Lovera, O. M., and Heizler, M. T.: 40Ar/39Ar results for alkali feldpsars containing diffusion domains with dif- fering activation energy, Geochim. Cosmochim. Acta, 55, 14351448, 1991.

Hatzfeld, D., Ziazia, M., Kementzetzidou, D., Hatzidimitriou, P., Panagiotopoulos, D., Makropoulos, K., Papadimitriou, P., and Deschamps, A.: Microseismicity and focal mechanisms at the western termination of the North Anatolian Fault and their implications for continental tectonics, Geophys. J. Int., 137, 891-908, 1999.

Jolivet, L., Brun, J. P., Gautier, P., Lallemant, S., and Patriat, M.: 3D-kinematics of extension in the Aegean region from the early Miocene to the present; insights from the ductile crust, Bulletin de la Societe Geologique de France, 165, 195-209, 1994.

Jolivet, L. and Patriat, M.: Ductile extension and the formation of the Aegean Sea, in: The Mediterranean basins: Tertiary extension within the Alpine orogen, edited by: Durand, B., Jolivet, L., Horvath, F., and Séranne, M., Geol. Soc. Spec. Publ., London, 156, 427-456, 1999.

Jolivet, L., Faccenna, C., Goffé, B., Burov, E., and Agard, P.: Subduction tectonics and exhumation of high-pressure metamorphic rocks in the Mediterranean orogens, Am. J. Sci., 303, 353-409, 2003.

Laigle, M., Hirn, A., Sachpazi, M., and Roussos, N.: North Aegean crustal deformation: An active fault imaged to $10 \mathrm{~km}$ depth by reflection seismic data, Geology, 28, 71-74, 2000.

Le Pichon, X. and Angelier, J.: The Aegean sea, Phil. Trans. R. Soc. Lond., A, 300, 357-372, 1981.

Lister, G. S., Banga, G., and Feenstra, A.: Metamorphic core complexes of cordilleran type in the Cyclades, Aegean Sea, Greece, Geology, 12, 221-225, 1984.

Lips, A. L. W., White, S. H., and Wijbrans, J. R.: 40Ar/39 Ar laserprobe direct dating of discrete deformational events; a continuous record of early Alpine tectonics in the Pelagonian Zone, NW Aegean area, Greece, Tectonophysics, 298, 133-153, 1998.

Lips, A. L. W., Wijbrans, J. R., and White, S. H.: New insights from 40Ar/39Ar laserprobe dating of white mica fabrics from the Pelion Massif, Pelagonian Zone, internal Hellenides, Greece; implications for the timing of metamorphic episodes and tectonic events in the Aegean region, in: The Mediterranean basins, Tertiary extension within the Alpine Orogen, edited by: Durand, B., Jolivet, L., Horvath, F., and Seranne, M., Geol. Soc. Spec. Publ., London, 156, 457-474, 1999.

Lovera, O. M., Richter, F. M., and Harrison, T. M.: The 40Ar/39Ar thermochronometry for slowly cooled samples having a distribution of diffusion domain sizes, J. Geophys. Res., 94, $17917-$ $17935,1989$.

Lovera, O. M., Richter, F. M., and Harrison, T. M.: Diffusion domains determined by 39Ar released during step heating, J. Geophys. Res., 96, 2057-2069, 1991.

Mascle, G. and Martin, L.: Shallow structure and recent evolution of the Aegean sea: a synthesis based on continuous reflection profiles, Mar. Geol., 94, 271-299, 1990.

McKenzie, D. P.: Active tectonics of the alpine-himalayan belt: the Aegean sea and surrounding region, Geophys. J. R. Astr. Soc., 30, 109-185, 1978.

McNeil, L. C., Mille, A., Minshull, T. A., Bull, J. M., Kenyon, N. H. and Ivanov, M.: Extension of the North Anatolian Fault into the North Aegean trough: Evidence for transtension, strain partitioning, and analogues for Sea of Marmara basin models, Tectonics, 23, TC2016, doi:10.1029/2002TC001490, 2004. 
Mercier, J. L., Sorel, D., Vergely, P., and Simeakis, K.: Extensional tectonic regimes in the Aegean basin during the Cenozoic, Basin Res., 2, 49-71, 1989.

Papanikolaou, D., Alexandri, M., Nomikou, P., and Ballas, D.: Morphotectonic structure of the western part of the North Aegean Basin based on swath bathymetry, Mar. Geol., 190, 465-492, 2002.

Passchier, C. W. and Trouw, R. A. J.: Microtectonics, Springer, Berlin, 289 pp., 1998.

Renne, P. R., Swisher, C. C., Deino, A. L., Karner, D. B., Owens, T. L., and DePaolo, D. J.: Intercalibration of standards, absolute ages and uncertainties in 40Ar/ 39Ar dating, Chem. Geol., 145(1-2), 117-152, 1998.

Ring, U., Will, T., Glodny, J., Kumerics, C., Gessner, K., Thomson, S., Güngör, T., Monié, P., Okrusch, M., Drüppel, K.: Early exhumation of high-pressure rocks in extrusion wedges: Cycladic blueschist unit in the eastern Aegean, Greece, and Turkey, Tectonics, 26, 2, TC2001, doi:10.1029/2005TC001872, 2007.

Roddick, J. C.: The application of isochron diagrams in 40Ar/39Ar dating, a discussion, Earth Planet. Sci. Lett., 41, 233-244, 1978.

Roddick, J. C., Cliff, R. A., and Rex, D. C.: The evolution of excess argon in alpine biotites, Earth Planet. Sci. Lett., 48, 185-208, 1980.

Schermer, E.: Geometry and kinematics of continental basement deformation during the Alpine Orogeny, Mt. Olympos region, Greece, J. Struct. Geol., 15, 571-591, 1993.

Schermer, E. R., Lux, D. R., and Burchfiel, B. C.: Temperature-time history of subducted continental crust, Mount Olympos region, Greece, Tectonics, 9, 1165-1195, 1990.

Van Hinsbergen, D. J. J., Langereis, C. G., and Meulenkamp, J. E.: Revision of the timing and distribution of Neogene rotations in the western Aegean region, Tectonophysics, 396, 1-34, 2005.

Walcott, C. R.: The alpine evolution of Thessaly (NW Greece) and late Tertiary Aegean kinematics, Geologica Ultraiectina, Utrecht University, 162, 176 pp., 1998.

York, D.: Least square fitting o a straight line with correlated errors, Earth Planet. Sci. Lett., 5, 320-324, 1969. 